\title{
Shedding some light on the metaphors of light (a Spanish-Chinese linguo-cultural contrast)
}

\author{
Rzucając nieco światła na metafory światła \\ (aspekt językowo-kulturowy w konfrontacji hiszpańsko-chińskiej)
}

\author{
Lei CHUNYI ${ }^{1}$ \\ University of Granada (Spain) \\ Antonio PAMIES ${ }^{2}$ \\ University of Granada (Spain)
}

\begin{abstract}
This paper compares Spanish and Chinese metaphoric lexical and phraseological units whose source domain is the opposition between light and shade. These units are collected, analysed and classified according to their figurative meanings. On the one hand, it is observed that several groups share the same target domains, such as FAITH vs. SIN, KNOWLEDGE vs. IGNORANCE, INTELLIGENCE vs. STUPIDITY, LEGITIMACY vs. CLANDESTINITY, and LIFE vs. DEATH among others. On the other hand, there are specific differences in the surface level of particular metaphors, but, mostly, striking coincidences at the more general level of linguo-cultural macromodels, taking into account the large linguistic and cultural gaps between the Spanish and the Chinese worlds.

Keywords: Cognitive theory of metaphor, cultureme, light, shade, Spanish phraseology, Chinese phraseology

1 https://orcid.org/0000-0002-5914-4063

La Universidad de Granada, Departamento de Lingüística General y Teoría de la Literatura Research Unit Lingüística Experimental y Tipológica (G.I.L.T.E) Junta de Andalucía (Spain) leichunyi@ugr.es

2 https://orcid.org/0000-0001-8193-9359

La Universidad de Granada, Departamento de Lingüística General y Teoría de la Literatura Research Unit Lingüística Experimental y Tipológica (G.I.L.T.E) Junta de Andalucía (Spain) apamies@ugr.es
\end{abstract}




\section{Streszczenie}

W niniejszym artykule porównano hiszpańskie i chińskie metaforyczne jednostki leksykalne i frazeologiczne, których domeną źródłową jest opozycja między ŚWIATŁEM a CIENIEM. Jednostki te zostały zebrane, przeanalizowane i sklasyfikowane zgodnie $\mathrm{z}$ ich znaczeniem przenośnym. Z jednej strony zaobserwowano fakt, iż kilka grup ma takie same domeny docelowe, takie jak między innymi WIARA vs. GRZECH, WIEDZA vs. IGNORANCJA, INTELIGENCJA vs. GŁUPOTA, LEGALNOŚĆ vs. TAJNOŚĆ, ŻYCIE vs. ŚMIERĆ. Z drugiej strony istnieją szczegółowe różnice w planie powierzchniowym poszczególnych metafor, ale przede wszystkim uderzające zbiegi okoliczności na bardziej ogólnym poziomie makromodeli językowo-kulturowych, biorąc pod uwagę duże różnice językowe i kulturowe między światem hiszpańskim a chińskim.

Słowa kluczowe: kognitywna teoria metafory, kulturem, światło, cień, frazeologia hiszpańska, frazeologia chińska

\section{Introduction}

Several dimensions of thought participate in metaphorical transfers between conceptual domains. Besides analogical thought, as in experiential metaphors (Lakoff 1983), we may include at least a part of logical reasoning (inferences, symmetrical correlations) and of socially inherited cultural symbolism (Dobrovol'skij \& Piirainen 2005). The latter is attested in language by allusions to culturemes, pre-linguistic symbols motivating lexical and phraseological metaphors (Pamies 2007; 2017). However, in the linguistic manifestations of these associative networks, there is not always a clear-cut boundary between experiential and cultural mappings: both mechanisms may cooperate in order to shape analogical, psychosensorial and cultural-ideological connections between concepts, reflected by language. A good example is the opposition between LIGHT and SHADE, which has obvious relations with the universal archi-metaphor that Lakoff calls KNOWING IS SEEING (1983), but also with religious connotations opposing positive and negative values in the Christian and Islamic world (Pamies \& Ghalayini 2018). This article, by means of comparing Spanish and Chinese languages, investigates the same source domain within a wider linguistic and cultural distance.

\section{Light and shade as religious culturemes}

In the Western world, the oldest cultural values of LIGHT are attested by the creationist mythologies. Hesiod's Theogony shows that ancient Greeks believed that Erebus and the black Night emerged from the Chaos, and that the Aether 
and the Day were born from Night (116-124) ${ }^{3}$. On the other hand, the Bible tells that God said, "Let there be light": and there was light, and also, that God saw the light, that it was good, and God divided the light from the darkness ${ }^{4}$.

- Dijo Dios: "Sea la luz" y fue la luz. (Génesis 1: 1-3)

- Y vio Dios que la luz era buena; y apartó Dios a la luz de las tinieblas (Génesis 1: 4-5).

Even though these two examples are talking literally about "real" LIGHT and SHADE, their positive/negative values predispose these concepts to the role they already played, since the beginning, in metaphors which appear in many other parts of the Bible, especially as symbols of FAITH and SIN, opposing the light of God (truth of revelation) to the Prince of Darkness. In fact, the word luz ("light") appears 383 times in the earliest complete Spanish version of the Bible (1569), with a figurative sense in most cases.

- El pueblo que andaba en tinieblas vio gran luz; los que moraban en tierra de sombra de muerte, luz resplandeció sobre ellos. (Isaías 9:2) "the people that walked in darkness have seen a great light: they that dwell in the land of the shadow of death, upon them hath the light shined".

- No se pondrá jamás tu sol, ni menguará tu luna; porque te será el señor por perpetua luz, y los días de tu luto serán acabados (Isaías 60:20) "the Lord shall be thine everlasting light, and the days of thy mourning shall be ended".

- ...Si morare en tinieblas, el señor es mi luz. (Miqueas 7:8) "when I sit in darkness, the Lord shall be a light unto me".

In the Gospels, Jesus Christ also used this image:

Yo soy la luz del mundo; el que me sigue no andará en tinieblas... (Juan 8:12) "I am the light of the world: he that followeth me shall not walk in darkness".

-...para que se conviertan de las tinieblas a la luz, y de la potestad de Satanás a Dios (Hechos: 26: 18) "to turn them from darkness to light, and from the power of Satan unto God".

\footnotetext{
${ }^{3}$ Hesiod. The Homeric Hymns and Homerica with an English Translation by Hugh G. EvelynWhite. Theogony. Cambridge, MA., Harvard University Press; London, William Heinemann Ltd. 1914 (http://www.perseus.tufts.edu/hopper/text?doc=Hes.+Th.+116).

${ }_{4}^{4}$ The quotations from the Spanish Bible are taken from Casiodoro de la Reina (1569), and the English equivalences are taken from the King James version (1611).
} 
Consequently, believers light up candles as a sign of devotion, and the iconography of the Christian church represents the Saints with an aureole 5 .

In Buddhism, the creation of the world is not a relevant matter for this issue, because its philosophy of time is based on the cycle of infinite life, with no beginning and no end. However, the omnipotent Buddha also "enlightens" all human beings, as still attested by some Chinese phrasemes:

-Fó guāng 佛光 *Buddha light "the powerful and beneficent influence of the Buddha on humanity and/or individuals" (Han yu ci dian 2008-2011).

-Fó guāng pǔ zhào 佛光普照 *Buddha light universally illuminate "the glory of Buddha is transmitted to everyone" (Ibid.).

-kāi guāng 开光 *open light (opening of light): "the ceremony of consecration in which something is sanctified, a kind of blessing that activates the magical powers of a protective object". It is a Buddhist term for consecration of a statue of a deity. While it is often performed in the Buddhist and Taoist faiths, it is also well known as the act of consecrating new lion costumes used for the traditional lion dance (Wikipedia) ${ }^{6}$.

\section{Light and shade as embodied mental models}

This ideological background partially overlaps a more experiential mental model: we understand better what we can see, thus LIGHT provides understanding and knowledge. The metaphorical macro-model KNOWING IS SEEING (Lakoff 1983), attested in English by idioms such as to clarify /I see what you're getting at /his claims aren't clear; /the passage is opaque, etc. which also exist in many other Western languages. This explains why the philosophers of the XVIII Century used LIGHT to represent the triumph of science on ignorance and superstition, a pattern easily imported by many European languages, since the underlying mental model, linking LIGHT and KNOWLEDGE, was already shared by the target languages because of the previous religious association. It motivates European metaphors such as:

\footnotetext{
${ }^{5} A$ radiant light around the head or body of a representation of a sacred personage (Merriam Webster Dictionary: http://www.merriam-webster.com/dictionary/aureole) (accessed November 2015).

${ }^{6}$ https://en.wikipedia.org/wiki/Kaiguang (accessed November 2015).
} 
-enlightened despotism = sp. despotismo ilustrado, fr. despotisme éclairé; grm. aufgeklärter Absolutismus; nl. verlicht despotisme; rs. просвещённый абсолютизм;

-(age of $)$ enlightenment $=$ sp. siglo de las luces /ilustración; fr. siècle des lumières /illustration; grm. Aufklärung; nl. verlichting; rs. (эпоха) просвещения.

This image has been opposed symetrically to obscurantism (sp. oscurantismo; fr. obscurantisme; grm. Obskurantismus, rs. обскурантизм), cleverly used by the Philosophers against the Church, which, long ago, had sacralized the ideological connotations of light.

In Spanish, we can find many figurative lexical and idiomatic meanings derived from this systematic association, where LIGHT represents KNOWLEDGE /UNDERSTANDING, and, symmetrically, DARKNESS represents IGNORANCE /MISUNDERSTANDING ${ }^{7}$.

\begin{tabular}{|c|c|}
\hline \multicolumn{2}{|c|}{ LIGHT IS KNOWLEDGE } \\
\hline -alumbrar ${ }^{*}$ enlighten & = "to teach" / "to explain" (cf. DRAE \#4) \\
\hline -aclarar/esclarecer ${ }^{*}$ to clear & = "to explain" \\
\hline -poner en claro (algo) *to put clear (sth.) & = "to explain in a simple manner" \\
\hline- ilustrar ${ }^{8}$ to illustrate & = "to help to understand" \\
\hline -ilustrado*illustrated & = "educated" / "cultured" \\
\hline -ilustrativo*illustrative & = "helping to understand sth." \\
\hline -iluminar ${ }^{*}$ to illuminate & = "to teach" (cf. DUE \# 6) \\
\hline -ser el faro (de algn.) *be the lighthouse & = "to be a guide for thought or knowledge" \\
\hline (of sb.) & $=$ "to provide information that helps \\
\hline -dar (/verter) luz ${ }^{*}$ to give /throw light & $\begin{array}{l}\quad \text { understanding" (DFDEA) = "to shed light" } \\
=\text { "to divulge new information" }\end{array}$ \\
\hline -sacar a la luz (añgo) *to take out to light & = "to be divulged" \\
\hline (sth.) & = "to understand suddenly" \\
\hline -salir a la luz ${ }^{*}$ to come out to light & = "a very good idea suddenly occurs" \\
\hline -hacerse la luz ${ }^{*}$ to make light & (to someone's mind) \\
\hline $\begin{array}{l}\text {-encendérsele la bombilla (a alguien) *the } \\
\text { light bulb turns+on+itself (to sb.) }\end{array}$ & $\begin{aligned}= & \text { "to begin to open one's mind to the rational } \\
& \text { knowledge of things" (cf. DRAE) }\end{aligned}$ \\
\hline -rayar la luz de la razón scratch the light & = "taking into account" (sth.) \\
\hline of the reason & = "obviously" \\
\hline -a la luz de (algo) *at the light of (sth.) & = "to be evident"; \\
\hline -a toda luz / todas luces* at all light(/s) & = "to be easy to understand" \\
\hline -estar claro* to be clear & = "to have no doubt" (about sth.) \\
\hline
\end{tabular}

${ }^{7}$ cf. English: clear; illustrate; clarify; clear up; shed (/throw /cast) light [on sth.]; to be brought into light; in the light of [sth.]; of the discussion springs the light; brilliant vs. obscure; dark; benighted; benightedness.

${ }^{8}$ From Lat. illustrare "make bright" (https://www.merriam-webster.com/) (accessed November 2015).

${ }^{9}$ From Lat. illuminare "to light up" (https:/www.merriam-webster.com/) (accessed November 2015). 


\begin{tabular}{|c|c|}
\hline $\begin{array}{l}\text { - ser transparente }{ }^{*} \text { to be transparent } \\
\text {-tener claro (algo) 'to have clear (sth.) } \\
\text {-de claro en claro* from clear to clear } \\
\text {-tan claro como la luz del día *as clear as } \\
\text { the daylight } \\
\text {-caérsele la venda de los ojos }{ }^{*} \text { the bandage fell } \\
\text { from the eyes }\end{array}$ & $\begin{array}{l}=\text { "more and more evident" } \\
=\text { "without any possibility of doubt" } \\
=\text { "to understand suddenly reality, in spite } \\
\text { of one's previous preconceptions" }\end{array}$ \\
\hline
\end{tabular}

\begin{tabular}{|c|c|}
\hline \multicolumn{2}{|c|}{ DARKNESS IS IGNORANCE } \\
\hline -tiniebla /oscuridad ${ }^{*}$ darkness & = "ignorance and confusion" \\
\hline -tenebroso*gloomy & = "incomprehensible" / "unknown" \\
\hline -oscuro*dark & = "incomprehensible"/ "unknown" \\
\hline -sombra ${ }^{*}$ shadow & = "incomprehension" / "ignorance" \\
\hline -oscurecer ${ }^{*}$ to darken & = "to prevent to be understood" \\
\hline -ofuscar ${ }^{*}$ to obfuscate $/{ }^{*}$ to darken & = "to create confusion in someone's mind" \\
\hline -ser opaco* to be opaque & = "to be difficult to understand" \\
\hline $\begin{array}{l}\text {-ceguera }{ }^{*} \text { blindness / ciego }{ }^{*} \text { blind } \\
\text { / cegar (a alguien) *to blind (sb.) }\end{array}$ & $\begin{aligned}= & \text { "inability to understand (sth.) because of one's } \\
& \text { preconceptions, beliefs, etc." }\end{aligned}$ \\
\hline -obedecer ciegamente ${ }^{*}$ to obey blindly & = "to obey orders without asking their reasons" \\
\hline -a oscuras /ciegas ${ }^{*}$ at dark /blind ones & = "without knowledge nor reflection" \\
\hline -cita a ciegas $*$ date at blind [persons] & $\begin{array}{l}=\text { "a meeting between two people previously } \\
\text { unknown to each other" }\end{array}$ \\
\hline -dar palos de ciego & $\begin{aligned}= & \text { "to search uncertainly without a method nor } \\
& \text { reliable knowledge" }\end{aligned}$ \\
\hline $\begin{array}{l}\text {-tener una venda en los ojos *to have a } \\
\text { bandage on one's eyes } \\
\text {-poner una venda en los ojos (a alguien) *to } \\
\text { put a bandage on the eyes (to someone else) }\end{array}$ & $\begin{array}{l}=\text { "not to be able to understand reality because of } \\
\text { one's beliefs or preconceptions" } \\
=\text { "to make (someone) become unable to } \\
\text { understand reality though it is obvious". }\end{array}$ \\
\hline -el amor es ciego *love is blind & = "no faults can be notices in the beloved one" \\
\hline -afición ciega razón *fondness blinds reason & $\begin{aligned}= & \text { "affection may prevent us from making objective } \\
& \text { decision or judgment, and can lead to cover up } \\
& \text { the defects of those we love" }\end{aligned}$ \\
\hline
\end{tabular}

The empirical basis of the association between KNOWING and SEEING may explain that we can also find examples of this association in Chinese. However, they are not as numerous and symmetrical as in Spanish.

LIGHT IS KNOWLEDGE

-jiān tīng zé míng, piān xìn zé àn (兼听则明, = "If you listen to both sides, you understand

偏信则暗) *simultaneously listen then clear, partial believe then dark (listening to all versions is clear, listening to only one is dark)

-kāi míng开明 *open bright (enlightenment) = "change from barbarism to civilization" 


\begin{tabular}{|c|c|}
\hline \multicolumn{2}{|c|}{ DARKNESS IS IGNORANCE } \\
\hline -y̌n hui隐晦*hide dark & ="obscure", "vague”, “ambiguous" (Han dian) \\
\hline 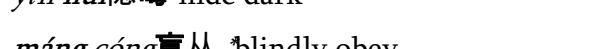 & = "obey thoughtlessly" \\
\hline -máng cóng目从 "blindly obey & = "marriage between a couple who unknown \\
\hline -máng hūn盲婚 *blind marriage & $\begin{array}{l}\text { each other, under the decision of their } \\
\text { parents or a matchmaker" (Han yu ci dian) }\end{array}$ \\
\hline $\begin{array}{l}\text {-wén máng 文盲 *character blind (blind to } \\
\text { read the characters) }\end{array}$ & = "illiterate" (Ibid.) \\
\hline
\end{tabular}

The difference may be due to the fact that the Philosophy of Enlightenment of the Western Philosophers had little influence on Chinese ideology, especially on political thought. According to Mathieu (2015):

Firstly, the ancient Chinese philosophers only ever thought in terms of monarchy (for the Zhou, in the form of a king, and in that of an Emperor for the Han). Secondly, even though some thinkers of the Confucian school concede that a prince should be "lucid" (which falls a little short of "enlightened"), in their eyes intellectual and mental perceptiveness does not appear to be indispensable to political and social progress [...] the very idea of mental and intellectual "enlightenment" is so alien to original Chinese thought that in modern Chinese the concept had to be given an artificial name: qimeng, which means, literally, "the opening of ignorance" [to new forms of truth]. It has since been popularized by authors such as $\mathrm{Lu}$ Xun (1881-1936), and even Mao Zedong (1893-1976), who gave it his own very personal interpretation. The term's translation into the vernacular speaks for itself, since it clearly focuses on abstract knowledge rather than any practical influence it might have on politics ${ }^{10}$.

\footnotetext{
${ }^{10}$ D'abord, les philosophes chinois de l'Antiquité n'ont jamais pensé autre chose que la monarchie (pouvoir du roi sous les Zhou, pouvoir de l'empereur à partir des Han). Deuxièmement, si certains penseurs de l'école confucianiste reconnaissent qu'un prince peut être "clairvoyant" (ne disons pas encore éclairé), la lumière intellectuelle ou mentale ne paraît pas considérée comme une caractéristique obvie d'une avancée politique ou sociale (....) l'idée même de «lumière» des mentalités ou des intelligences est-elle absente de la pensée chinoise originelle, à tel point que la notion a dû être rendue par une expression artificielle en chinois moderne: celle de qimeng, c'est-à-dire, littéralement, d'«ouverture de l'ignorance» [à des vérités neuves], comme l'ont vulgarisée les auteurs tels Lu Xun (1881-1936), puis Mao Zedong (1893-1976) lui-même, on voit bien dans quel état d'esprit. Cette traduction est, en elle-même, une indication, puisqu'elle ne semble viser que la connaissance et non point le champ politique au sein duquel elle s'opérerait (English translation is ours).
} 


\section{Metonymical extensions of metaphors}

Once LIGHT and SHADE are associated to the target domains of KNOWLEDGE and IGNORANCE, this "connection" can be extended to other concepts which are conceptually contiguous to these targets.

\subsection{LIGHT is INTELLIGENCE, DARKNESS is STUPIDITY}

In both languages, the association to KNOWLEDGE involves, by metonymy, the individual capacity of understanding (INTELLIGENCE), which may also be represented by LIGHT. Symmetrically, STUPIDITY is symbolized by DARKNESS, and, by means of a secondary extension, implies BLINDNESS, SHORTSIGHTEDNESS, etc.

\begin{tabular}{|c|c|}
\hline \multicolumn{2}{|r|}{ LIGHT IS INTELLIGENCE } \\
\hline- luz ${ }^{*}$ light & $=$ "clarity of mind" (DRAE \#14) \\
\hline -lumbre light & $=$ "intelligence and reason" (DUE \#12) \\
\hline $\begin{array}{l}\text {-luz de la razón light of the } \\
\text { reason, }\end{array}$ & $\begin{aligned}= & \text { "knowledge of things, which comes from natural speech..." } \\
& \text { (DAUT: IV). }\end{aligned}$ \\
\hline -lucidez ${ }^{*}$ lucidity & $=$ "capacity to perceive the truth on a rational way" \\
\hline -lúcido 'ucid & $=$ "able to perceive the truth in spite of confusion" \\
\hline -mente clara ${ }^{*}$ clear mind & $\begin{array}{l}=\text { "able to perceive the truth in spite of confusion", } \\
\text { [cf. eng. clearheaded] }\end{array}$ \\
\hline -clarividente ${ }^{*}$ clear-seeing & $\begin{array}{l}=\text { "able to able to perceive the truth" in spite of confusion", } \\
\text { [cf. fr./eng. clairvoyant] }\end{array}$ \\
\hline -mente brillante ${ }^{*}$ brilliant mind & $=$ "brilliant mind" \\
\hline -idea brillante shiny idea & = "brilliant idea" \\
\hline -idea luminosa luminous idea & = "excellent idea" \\
\hline
\end{tabular}

\begin{tabular}{|ll|}
\hline \multicolumn{2}{|c|}{ LIGHT IS INTELLIGENCE } \\
\hline -míng rén bù bì xì shuō 明人不必细说 *clear & $=$ "it is not necessary explain many things to \\
person not necessary in+detail say & intelligent people, a few words are enough" \\
- yǒu yăn guāng 有眼光 "have eye light (to have & $=$ "to be able to evaluate and appreciate the right \\
a light in one's eye) & things" \\
-míng hui明慧 *lear wise & $=$ "intelligent" \\
-míng zhi 明智* clear wise & $=$ "wise; reasonable" \\
\hline
\end{tabular}

\section{DARKNESS IS STUPIDITY}

\begin{tabular}{|c|c|}
\hline -hombre de pocas luces *man of few lights & $=$ "foolish male" \\
\hline -no ser ninguna lumbrera ${ }^{*}$ not to be a luminary & $\begin{array}{l}=\text { "to be completely stupid" (euphemism by } \\
\text { litotes) }\end{array}$ \\
\hline $\begin{array}{l}\text {-no ver más allá de sus narices }{ }^{*} \text { not to see beyond } \\
\text { one's own nose }\end{array}$ & $\begin{aligned}= & \text { "unable to make foresights", "who thinks } \\
& \text { only at short-term", [cf. eng. short-sighted] }\end{aligned}$ \\
\hline
\end{tabular}




\begin{tabular}{|c|c|}
\hline \multicolumn{2}{|c|}{ DARKNESS IS STUPIDITY } \\
\hline -yú mèi愚昧 *stupid obscure & $=$ "fatuous" \\
\hline -hūn jūnn 昏君 *obscure monarch & $=$ "fatuous and intemperate monarch" \\
\hline $\begin{array}{l}\text {-mù guāng rú dòu 目光如豆 *eye light seem } \\
\text { legume (sight as small as a legume) }\end{array}$ & $\begin{array}{l}\text { = "inability of a long-term reasoning"; } \\
\text { "shortsightedness" }\end{array}$ \\
\hline $\begin{array}{l}\text {-shǔ mù cùn guāng鼠目寸光 *rat/mouse eye } \\
\text { inch" light ("the light measure of mouse } \\
\text { eyes) }\end{array}$ & $\begin{aligned}= & \text { "shortsighted", "unable to preview the } \\
& \text { consequences of one's own acts" }\end{aligned}$ \\
\hline -àn mèi 暗昧 *dark without+notion & = "stupid and ignorant" \\
\hline -hūn yōng昏庸 *dark mediocre & = "stupid and fatuous" (Sun Yizhen 2002:372) \\
\hline
\end{tabular}

\subsection{LIGHT is LEGITIMACY, DARKNESS is CLANDESTINITY}

There is a causative contiguity between KNOWLEDGE and TRUTH, and, symmetrically, between IGNORANCE and DECEPTION (showing vs. concealing the truth). Therefore, the symbolism of LIGHT/SHADE may also be extended metonymically to this opposition. Since DARKNESS helps to hide secret (or forbidden) things, this opposition has also connotative links with ILLEGALITY.

\begin{tabular}{|ll|}
\hline \multicolumn{2}{|c|}{ LIGHT IS LEGITIMACY } \\
\hline -a las claras to the clear ones & $=$ "sincerely" \\
-hablar claro*speak light & $=$ "to speak frankly" \\
-a plena luz del día *at full daylight & $=$ "not hiding", in broad daylight \\
- transparencia "transparency & $=$ "avoiding corruption" \\
-con luz y taquígrafos "with light and & $=$ "with total access to information about a public \\
stenographers & event" \\
-claro y raspado*clear and scraping & $=$ "very frankly" (DRAE 2014). \\
\hline
\end{tabular}

\begin{tabular}{|ll|}
\hline \multicolumn{2}{|c|}{ DARKNESS IS CLANDESTINITY } \\
\hline -a oscuras *at dark ones (in the dark) & $=$ "secretly; clandestinely" \\
-de tapadillo* of covered & $=$ "stealthily" [cf. eng. under the table] \\
-opacidad *pacity & $=$ "lack of information and legal control" \\
-gobierno en la sombra "government in the & $=$ "secret or invisible power which controls the \\
shadow (shadow government) & actual political authorities"; [cf. eng. shadow \\
& government] \\
-oscura conspiración ${ }^{*}$ dark conspiracy & $=$ "secret political activity against someone" \\
\hline
\end{tabular}

${ }^{11}$ The cùn $\left({ }^{*}\right.$ thumb) is a traditional Chinese unit of measure (1 cùn=1.463 inches). 
This conceptual mapping is also attested in Chinese in its two poles:

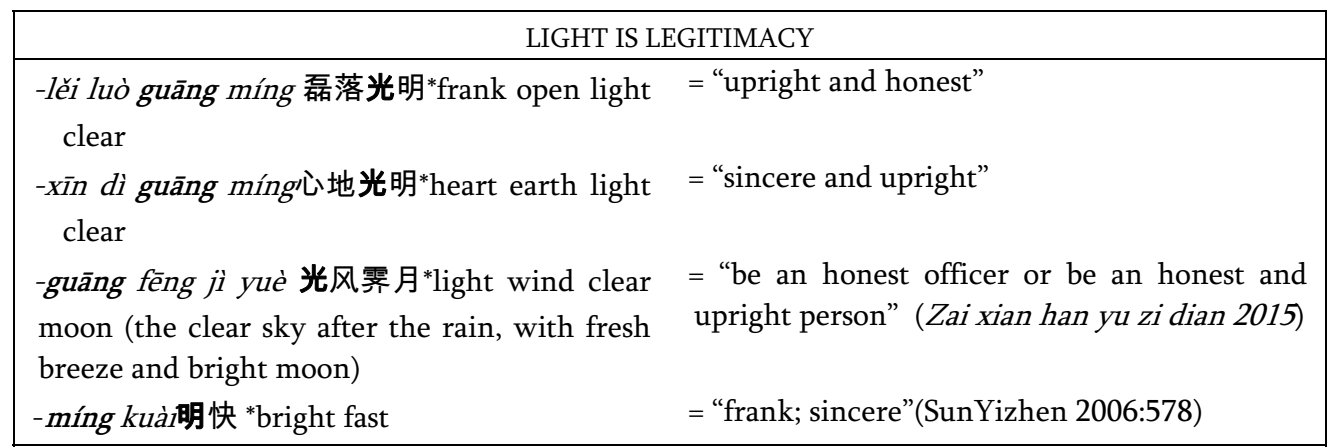

\begin{tabular}{|c|c|}
\hline \multicolumn{2}{|c|}{ DARKNESS IS CLANDESTINITY } \\
\hline -míng rén bù zuò àn shi 明人不做暗事 & = "an honest person will not do anything \\
\hline${ }^{*}$ clear person not do dark event & underhand” (Sun Yizhen 2006: 577) \\
\hline -yīn móu gul ji阴谋论计 & = "conspiracies and plots; intrigue and \\
\hline *dark schemes sly stratagem & miachiavellian tricks" (Han yu ci dian) \\
\hline -àn xiāng cāo zuò暗箱操作 & $=$ "an event or an activity is performed \\
\hline *dark box operate do & clandestinely" (Ibid.) \\
\hline -yīn xiăn 阴险*dark dangerous & = "insidious", "treacherous" (Han dian) \\
\hline -yīn sǔn阴损 *dark harm & = "hurt secretly" (Ibid.) \\
\hline
\end{tabular}

\subsection{LIGHT is HONOUR, DARKNESS is ANONYMITY or BAD REPUTATION}

Another metonymy, more grounded on Spanish culture than on any experiential basis, makes the religious LIGHT/SHADE symbolism of GLORY to be extended to neighboring concepts, such as SUCCESS, FAME and HONOUR ${ }^{12}$. Symmetrically, DARKNESS can represent its opposite, ANONYMITY or even BAD REPUTATION ${ }^{13}$. We can also find spontaneous metaphors into creative discourse, derived from the same model: for example, se apagó su luz ("his light was turned off) meaning "his celebrity began to vanish". In the following example, a basketball player is described metaphorically with the image of light (luz): el pívot llegó como estrella NBA en la temporada 2001-2002, procedente de Chicago, y su luz se apagó poquito a poco, hasta pasar desapercibido

\footnotetext{
${ }^{12} \mathrm{cf}$. English: the light of fame; to be brilliant; to become a star; to be on the spotlight.

${ }^{13} \mathrm{cf}$. English: to remain in obscurity; to slide into obscurity; to fade into obscurity; to obscure someone's identity.
} 
por la $A C B^{14}$ ("the pivot came as a NBA star in the 2001-2002 season, coming from Chicago, and his light faded little by little, until passing unnoticed in the ACB”).

\begin{tabular}{|c|c|}
\hline \multicolumn{2}{|c|}{ LIGHT IS SUCCESS-FAME-HONOUR } \\
\hline - brillante ${ }^{*}$ shiny & $=$ "famous" \\
\hline - brillar ${ }^{*}$ to shine & ="be outstanding; to excel in talent" (DRAE) \\
\hline - estrella de cine ${ }^{*}$ star of movies & $=$ "famous movie actor" [cf. Hollywood star] \\
\hline $\begin{array}{l}\text { - estar en el candelero }{ }^{*} \text { to be in the limelight } \\
\text { /candlestick }\end{array}$ & $\begin{aligned}= & \text { "to get attention and interest from the public", } \\
& {[\text { cf. eng. to be in the spotlight }] }\end{aligned}$ \\
\hline - lucirse ${ }^{*}$ to twinkle & $=$ "to show off" \\
\hline - lucimiento ${ }^{*}$ sparkle, ${ }^{*}$ brilliance & = "the show off" \\
\hline - ilustre *illustrious & = "distinguished" \\
\hline - ilustrísimo*very illustrious & $\begin{array}{c}=\text { "honorable", "Excellency" (Spanish standard } \\
\text { forms of address for ministers and deans) }\end{array}$ \\
\hline
\end{tabular}

\begin{tabular}{|ll|}
\hline \multicolumn{2}{|c|}{ DARKNESS IS ANONYMITY OR BAD REPUTATION } \\
\hline - personaje oscuro *dark character & $=$ "modest and completely unknown person" \\
- personaje gris ${ }^{*}$ grey character & $=$ "not outstanding person" \\
- oscuridad $^{*}$ darkness & $=$ "anonymity" \\
- denigrar (a alguien) *to darken (sb.) & $=$ "to harm the reputation (of sb)", [cf. eng. \\
& to denigrate] ${ }^{15}$ \\
\hline
\end{tabular}

In Chinese there are some similar associations. As already mentioned, in spite of their great differences, Christian and Buddhist cultural traditions share the religious association between the image of LIGHT and the religious concept of GLORY. Modern Chinese culture has even extended this connection to VICTORY, as it is reflected, for example, in the iconography of the posters for the "Army Day" ( $1^{\text {st }}$ of August), where the five-star is shining with a great aureole, or in the lyrics of a famous patriotic song titled 五星红旗永远放光芒 (Wǔ xīng hóng qí yǒng yuăn fảng guāng máng). Its literal meaning is "the fivestar red flag shines forever", and it expresses figuratively that the People's Republic of China will achieve glory and success.

${ }^{14}$ El Mundo, Supl. Deporte 17/02/2003 (accessed November 2015).

15 <Lat. denigrare *to paint in black: "to darken" (compound: de "from" + niger "black") [DRAE] (accessed November 2015). 


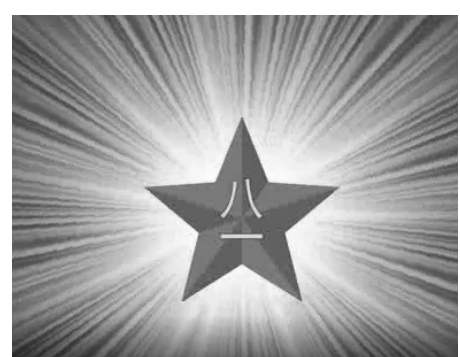

(Kua Fu Zhui Ri: Poster for China's Army Day) ${ }^{16}$

As attested in language, this polysemy has been also extended metonymically to HONOUR, since the word guāng光 (*light) is a component of several courteousness idiomatic formulae expressing the respect of the host to his guests (Sun Yizhen 2002). Symmetrically, DARKNESS is related to FAILURE and DISHONOUR.

\begin{tabular}{|c|c|}
\hline \multicolumn{2}{|c|}{ LIGHT IS HONOUR } \\
\hline $\begin{array}{l}\text { - zhēng guāng争光*compete light (compete for light) } \\
\text {-guāng lín 光临 *light arrive / guāng jià 光驾*light } \\
\text { float (Sun Yizhen 2002) }\end{array}$ & $\begin{array}{l}=\text { "gain honors" } \\
=\text { "two formulae of courtesy to express } \\
\text { that the presence of the guest has brought } \\
\text { honour to the host" }\end{array}$ \\
\hline - jìng qǐng guāng lín 敬请光临 *respectably request & = "your presence is cordially requested" \\
\hline $\begin{array}{l}\text { light arrive (Ibid.) } \\
\text { - gōng hòu dà jià guāng lín } \\
\text { 恭候大驾光临*respectfully expect big float light } \\
\text { arrive (Ibid.) }\end{array}$ & $\begin{array}{l}=\text { "the presence of the guest has brought } \\
\text { honor to the host" }\end{array}$ \\
\hline $\begin{array}{l}\text { - huān yíng guāng gù 欢迎光顾 *happy receive light } \\
\text { arrive (Ibid.) }\end{array}$ & $\begin{array}{l}\text { = "we request the pleasure of your } \\
\text { company" }\end{array}$ \\
\hline $\begin{array}{l}\text { - huān yíng guāng gù欢迎光顾 *glad to receive light } \\
\text { buy (Ibid.) }\end{array}$ & $\begin{array}{l}=\text { "welcome, glad to have you presence" / } \\
\text { "thank you for coming" }\end{array}$ \\
\hline \multicolumn{2}{|c|}{ DARKNESS IS ANONYMITY OR BAD REPUTATION } \\
\hline $\begin{array}{l}\text { - liăn shàng wú guāng脸上无光 } \\
\text { *face on without light (dark faced) }\end{array}$ & ishonoured" (Zai xian xin hua zi dian) \\
\hline - mǒ hēi抹黑 *spread dark & edit (someone)" (Ibid.) \\
\hline
\end{tabular}

16 傲视网 (Ao Shi Website) [07-07-2016], design by 夸父追日 (Kuā Fù Zhuī Rì) (accessed 20-032020) (http://www.aoao365.com/hc/jieri/2016102052.html). 


\subsection{LIGHT is HOPE, DARKNESS is DESPAIR}

Another metonymy relates the "physical" light to the religious LIGHT/SHADE metaphors, in order to symbolize HOPE/DESPAIR. For sailors and fishermen, the hope of survival depended mainly on the weather, opposing the darkness of stormy weather to the sunlight of quiet seas, motivating, for example, the English proverb, every cloud has a silver lining. More recently, mine industry motivated the image of the light at the end of the tunnel, derived from a similar association between LIGHT and HOPE, or DARKNESS and DESPAIR ${ }^{17}$. The background of the theological metaphor of hope and faith is strengthened by this added metonymic connection, attested in Spanish language by figurative expressions such as:

\begin{tabular}{|c|c|}
\hline \multicolumn{2}{|r|}{ LIGHT IS HOPE } \\
\hline -un rayo de luz*a ray of light & = "something that provides a small amount of hope or \\
\hline$=$ rayo de esperanza "ray of hope & happiness in a difficult situation" \\
\hline -ver la luz ${ }^{*}$ to see the light & $\begin{array}{l}=\text { "to have positive expectations after a long period of } \\
\text { difficulties" }\end{array}$ \\
\hline $\begin{array}{l}\text {-la luz al final del túnel* the light at the } \\
\text { end of the tunnel }\end{array}$ & = "first positive signals after a long period of troubles" \\
\hline -futuro radiante* shiny future & = "expectedly good future", [cf. eng. bright future] \\
\hline -futuro brillante *shiny future & $=$ "future with good prospects" [cf. eng. brilliant future] \\
\hline
\end{tabular}

\begin{tabular}{|ll|}
\hline \multicolumn{2}{|c|}{ DARKNESS IS DESPAIR } \\
\hline -negra desesperación black despair & $=$ "complete despair" \\
-oscuros presagios *dark omens & $=$ "pessimistic premonitions" \\
-tenerlo/verlo muy negro *to have/see it very & $=$ "situation in which one cannot expect anything \\
black & good" [cf. eng. to have dark future] \\
- oscuro futuro*dark future & $=$ "bad expectations", [cf. eng. dark future] \\
-porvenir tenebroso* gloomy future & $=$ "bad expectations", [cf. eng. dark future] \\
-llegar (/venir) nubarrones thunderclouds & $=$ "something bad will happen" \\
are arriving (/coming) &
\end{tabular}

\footnotetext{
${ }_{17}$ Cf. English: bright future, brilliant future vs. dark future, gloomy view, obscure premonition, dark pessimism, to be full of gloom and doom, to be a doom-and-gloomer.
} 
The same cultural symbolism is reflected in Chinese lexicalized metaphors such as:

\begin{tabular}{|c|c|}
\hline \multicolumn{2}{|c|}{ LIGHT IS HOPE } \\
\hline $\begin{array}{l}\text {-guāng míng dà dào 光明大道 light bright } \\
\text { big road }\end{array}$ & $\begin{aligned}= & \text { "good expectations" (Zai xian xin hua zi dian), } \\
& \text { [cf. eng. bright future }]\end{aligned}$ \\
\hline -shǔ guāng 曙光 *dawn light & = "hope" (Ibid.) \\
\hline $\begin{array}{l}\text {-yáng guāng gōng chéng阳光工程 *sunlight } \\
\text { program }\end{array}$ & $\begin{array}{l}=\text { "name of a Chinese welfare program to fund } \\
\text { schools for poor children by means of public } \\
\text { donations" }\end{array}$ \\
\hline
\end{tabular}

\begin{tabular}{|c|c|}
\hline \multicolumn{2}{|c|}{ DARKNESS IS DESPAIR } \\
\hline $\begin{array}{l}\text { - qián jĩng àn dàn 前景堷淡 } \\
\text { *front panorama dark little+dense (the future } \\
\text { panorama is dark) }\end{array}$ & $\begin{array}{l}=\text { "to have poor expectations for the future; "to } \\
\text { have an unattractive future" (Sun Yizhen } \\
\text { 2006: 7) }\end{array}$ \\
\hline $\begin{array}{l}\text {-hui qi 晦气*dark air } \\
\text { - jīn tiān zhēn hēi今天真黑! *today is very } \\
\text { dark }\end{array}$ & $\begin{array}{l}=\text { "misfortune; unluckiness" (a kind of formula to } \\
\text { express a "bad day") } \\
=\text { "today is very unlucky day!" }\end{array}$ \\
\hline
\end{tabular}

\section{Linguo-cultural gaps}

As far as metaphoric macro-models are concerned, the above-mentioned data on Spanish and Chinese show striking similarities between these typologically unrelated languages. However, there are some important discrepancies as well. One of the major differences is that, in Chinese, the LIGHT may also have negative connotations, and, especially in these cases, there is no symmetrical opposition with DARKNESS. There are at least three Chinese metaphorical models in which, unlike Spanish, negative values are symbolized by light: NAKEDNESS, EMPTINESS and LONELINESS.

\subsection{LIGHT is NAKEDNESS}

\begin{tabular}{|ll|}
\hline - guāng tóu 光头 *luminous head & $=$ "bald head" (Sun Yizhen 2006) \\
- guāng jiăo 光脚 *luminous foot & $=$ "barefoot" (Ibid.) \\
- guāng tū tū光秃秃 *luminous bare bare & $=$ "uncovered"; "bare" (Ibid.) \\
- guāng băng zi 光膀子 *luminous arm SUF. & $=$ "naked in the upper part of the body" [for \\
& males] (Ibid.)
\end{tabular}




\subsection{LIGHT IS EMPTINESS}

By extension of the idea of nudity, the image of LIGHT also refers to the EMPTINESS and EXHAUSTION in a more general way. The character guāng (光 *light) may express "to leave nothing" and even "to spend one's entire fortune".

$$
\begin{aligned}
& \text { chī guāng 吃光 *eat light "eat up (all); } \\
& \text { mài guāng 卖光 *sell light "sell up (all). }
\end{aligned}
$$

There is a relatively modern idiom, yuè guāng zú [月光族 ("moon light group) "people of moonlight", which is referring ironically to those who always spend all their wages before the end of the month, who barely "make ends meet"18.

\subsection{LIGHT is LONELINESS}

The word guāng光 ("light") may indicate "without family, company, partner, followers, etc.". For example, a man of marriageable age who still stays single is called guāng gùn (光棍 *light stick "single", “celibate”).

Chinese culture places great emphasis on having offspring. In a certain sense, the descendants are compared to the "branches and leaves of the tree", while the parents are compared to the "trunk". When a man has no wife, it means that he will have no descendants, like a debarked stick. The expression guāng gănr光杆儿 *light stick SUF. ("barked stick") refers to "one who has lost all his family and left alone; orphan" or "someone without follower or people who support him" (Han yu ci dian).

\subsection{LIGHT is LIFE, DARKNESS is DEAD}

Conversely, Spanish has a figurative association which is absent in Chinese: the metaphoric model linking LIGHT to BIRTH and DARKNESS to DEATH.

\footnotetext{
${ }^{18}$ This term is in fact a word pun, since the expression yuè guāng月光 ("moon light) can be understood in two different ways, either "moon light" or "to spend all the money before the end of the month", depending on its context. In Chinese, the character for "moon" and for "month" is the same (月), and the pronunciation is also homophonic (yuè).
} 
In Spanish, the opposition LIGHT/SHADE symbolizes LIFE and DEATH, probably as a metonymical extension of its religious symbolism.

In modern Spanish, ver la luz ("see the light) means "to be born", while dar a luz ("to give at light) and alumbrar ("to enlighten) mean "to give birth", and alumbramiento ("enlightenment) means "labor". The first academic dictionary (DAUT 1726) defined this word by using cyclically the LIGHT metaphor inside the definition: ...el buen suceso en el parto que sale a luz con felicidad (literally: the good event in the labor which comes out to light with happiness).

Symmetrically, apagarse and extinguirse (*to extinguish) mean euphemistically "to die", and the same metaphor motivates that extinción ("extinction) may also mean "to die", e.g. in the phraseo-term especies en peligro de extinción ("species in danger of extinction "endangered species"), or in euphemistic funerary formulae similar to English pass away.

E.g., Ya hace un año que su luz se apagó y su lucha pasó a ser la nuestra y su recuerdo, nuestra fuerza para seguir adelante *already a year ago his light was extinguished, and his struggle became ours and his memory became our strength to continue ${ }^{19}$.

By an additional extension of the BIRTH metaphor, salir a (la) luz (*to come out to light) also means "be produced" if applied to a new device, or "to be published" if applied to a new book, as well as ver la luz ("to see the light) (DFDEC 2009). Likewise, sacar a la luz [un libro] ("to take out to light [a book]) and dar a luz [una obra] ("to give light [a literary work]) mean "to publish a new book” (/novel /essay) (DRAE 2014, \#2), whereas alumbrar [un poema] (*enlighten [a poem]) means "to write/compose a poem" (DUE 2008, \#8).

In Chinese culture, we do not find linguistic evidences of such a cultural value for this symbol, since the BIRTH of a baby is not associated with LIGHT in fixed metaphors ${ }^{20}$. Likewise, Chinese neither uses the image of "extinction"

\footnotetext{
${ }^{19}$ Fundación Josep Carreras Contra la Leucemia: (https://www.facebook.com/fundacioncarreras/ photos/pb.403285996037.-2207520000.1460286957/10154746802111038/?type=3\&theater) (accessed November 2015).

${ }^{20}$ Chinese uses MOVEMENT metaphors, such as jiàng sheng (降生*drop life) “a new life drops to the world"; chū shi (出世*'come+out world) “a new life arrives in the world”; chū sheng (出生*come out life) "a new life comes out".
} 
to represent DEATH of individual persons ${ }^{21}$ nor the extension of LIGHT to the fact of publishing or writing a book.

There is perhaps one exception, when speaking about the "death" of a whole nation or about the end of a historical period, we may find the "extinction" metaphor in the compound miè wáng灭亡 [*extinguish die] (Han Dian). In ecological discourse, the disappearance of certain species may also be expressed by means of the "extinction" image. E.g. miè jué灭绝 *extinguish "die out" (Han Dian). Maybe it is a Western borrowing, but it could also be linked to Chinese culture: the infinite cycle of Buddhist reincarnation affects only the birth/death of individuals, while political collectivities and institutions, historical periods or the existence of biological species, may have a beginning and an ending.

\section{Conclusions}

There are many similar metaphors of LIGHT/SHADE in Spanish and Chinese, although both languages only share partially this cultureme. Even if particular metaphors are quite different, the image of LIGHT, opposed to DARKNESS, organizes a rich system of conceptual links in both languages, mostly based on a cultural nature, symmetrically related to DIVINITY /DEVIL, TRUTH /DECEPTION, KNOWLEDGE /IGNORANCE, UNDERSTANDING /MISUNDERSTANDING, INTELLIGENCE /STUPIDITY, GLORY /ANONYMITY, LEGITIMACY /CLANDESTINITY, HOPE /DESPAIR.

Regardless of the similarities mentioned above, some important discrepancies have also drawn our attention; among them we have observed that in Chinese, the LIGHT can also carry negative connotations. Besides, in such cases, there is no symmetrical opposition with DARKNESS. Due to the particular beliefs and traditions of China, there is a series of metaphors of LIGHT with negative values that have no correspondence in Spanish, namely NAKEDNESS, EMPTINESS, AND LONELINESS.

On the other hand, we may also find some peculiarities in the Spanish metaphors of LIGHT/SHADE: they can symbolize the opposition BIRTH/DEATH in Spanish, whereas this couple of values is not evident in Chinese.

\footnotetext{
${ }^{21}$ Instead, we rather find concepts such as "to leave the world", e.g. qù shì (去世*go+away world) / lí shi (离世 *leave world) / shi shi (逝世*depart world) / guò shi (过世*pass world) or "to bid farewell to the world", e.g. cí shi (辞世*say+goodbye world), or even "wither", e.g. xiè shi (谢世*wither+away world).
} 


\section{REFERENCES}

Dobrovol'skij, D. O. \& Piirainen, E. (2005). Figurative Language: Cross-cultural and Crosslinguistic Perspectives. Amsterdam: Elsevier.

Lakoff, G. (1993). The Contemporary Theory of Metaphor. In: Ortony, A. (ed.) Metaphor and Thought (2nd ed.), Cambridge University Press.

Chunyi Lei (2015). La flor de loto en el léxico figurado y fraseología en chino, Paremia, 24, pp. 53-59.

Mathieu, R. (2015). La Lumière dans les ténèbres: le taoïsme originel dans la Chine antique. Rue Descartes, 1/84, pp. 11-19. DOI: 10.3917/rdes.084.0011, https://www.cairn.info/revuerue-descartes-2015-1-page-11.htm

Pamies, A. (2007). El lenguaje de la lechuza: apuntes para un diccionario intercultural. In: Luque, J.d.D \& Pamies, A. (eds.) Interculturalidad y lenguaje: El significado como corolario cultural. Granada: Granada Lingvistica, vol. 1, pp. 375-404.

Pamies A. (2017). The concept of cultureme from a lexicographical point of view. Open Linguistics 3(1), pp. 100-114. DOI: https://doi.org/10.1515/opli-2017-0006

Pamies, A. \& Ghalayini, Y. El (2018). La métaphore de la lumière à la lumière de la métaphore (français-arabe). In: Blanco, X. \& Sfar, I. [eds.] Lexicologie(s): approches croisées en sémantique lexicale. Frankfurt: Peter Lang, pp. 227-254. DOI: https://doi.org/10.3726/b13243

\section{Dictionaries}

DAUT Real Academia Española 1726-1739. Diccionario de autoridades. 6 vols. Madrid: Imprenta de Francisco del Hierro (reed. facsímil http://web.frl.es/DA.html).

DFDEA Seco, M.; Andrés, O. \& Ramos, G. (2004). Diccionario fraseológico documentado del español actual: Locuciones y modismos españoles (DFDEC). Madrid: Aguilar-Santillana [2a ed. 2009].

DRAE Real Academia Española (2014). Diccionario de la lengua española. 23.a edición (http://www.rae.es/).

DUE Moliner Ruiz, M. (2008). Diccionario de uso del español. Madrid: Gredos.

HAN DIAN 汉典 (“Chinese online dictionary”) (2004-2015). (http://www.zdic.net/).

MERRIAM-WEBSTER (1983). Merriam-Webster's Collegiate Dictionary $\left(11^{\text {th }} \mathrm{ed}.\right)$ (http://www.merriam-webster.com).

SUN Yizhen孙义桢 (2006). 《新汉西词典》(“New Chinese-Spanish dictionary”). Beijing: Shang wu yin shu guan商务印书馆.

ZAI XIAN XIN HUA ZI DIAN (2015-2019). (“Xinhua Chinese online dictionary”), 在线新华字典 (http://xh.5156edu.com). 